\title{
Managing Diamide Resistance in Florida Tomato ${ }^{1}$
}

\author{
Hugh A. Smith ${ }^{2}$
}

Diamides belong to a recently developed class of insecticides that disrupt ryanodine receptors, intracellular calcium channels that play a central role in muscle and nerve function. Diamide insecticides are systemic-they can be taken up by the plant's vascular system either through the roots or foliage. Systemic insecticides can be applied to the plant in transplant water, through drip irrigation, and directly to the foliage. There are presently three diamide insecticides available for use on tomatoes in Florida: chlorantraniliprole, cyantraniliprole, and flubendiamide. Chlorantraniliprole and cyantraniliprole are also referred to as rynaxypyr and cyazypyr, respectively. Chlorantraniliprole, the active ingredient in Coragen, became available in 2008, and flubendiamide, the active ingredient in Belt and Synapse, became available in 2009. Cyazypyr became available in 2013, sold as Verimark for soil application and Exirel for foliar application. Diamide insecticides have been assigned the mode of action classification number 28 by the Insecticide Resistance Action Committee (www.irac-online.org). This number appears on the label of any insecticide containing diamides. Chlorantraniliprole, flubendiamide and cyantraniliprole are available in additional formulations and in some products combined with other insecticides (Table 1).

Flubendiamide is primarily active against caterpillar pests. Key caterpillar pests of Florida tomato that can be managed with flubendiamide include cutworms, tomato fruitworm (Helicoverpa zea), tomato pinworm (Keiferia lycopersicella), southern armyworm (Spodoptera eridania), beet armyworm (Spodoptera exigua), and yellowstriped armyworm (Spodoptera ornithogalli). Other caterpillar pests attacking tomato that can be managed with flubendiamide include tobacco hornworm (Manduca sexta), cabbage looper (Trichoplusia ni), and soybean looper (Pseudopludia includens).

Chlorantraniliprole is effective against the same complex of caterpillar pests of tomato as flubendiamide. In addition, chlorantraniliprole suppresses nymphs of the silverleaf whitefly, Bemisia tabaci biotype B, and can be used to manage the larvae of serpentine and vegetable leafminers (Liriomyza sativae and L. trifolii). Cyantraniliprole is effective against both adults and nymphs of the silverleaf whitefly, in addition to killing leafminer and caterpillar pests. The silverleaf whitefly vectors Tomato yellow leaf curl virus (TYLCV), which can cause devastating losses in tomato in Florida and other regions of the world.

As with any insecticide, repeated use of diamide insecticides on successive generations of the same pest may lead to the development of insecticide resistance. In order to avoid the development of resistance to diamides by targeted pests of tomato, group 28 insecticides must be rotated with insecticides possessing different modes of action. Insecticide modes of action available for management of silverleaf whitefly, caterpillars, and leafminers on Florida tomato are listed in Table 2.

In order to conserve the efficacy of diamide and other insecticides, a "treatment window" approach can be employed. A treatment window is a period of time that is defined by the crop stage, the biology of the pest complex attacking the crop, or a combination of both. Tomato crops are most vulnerable to TYLCV during the first five or six

1. This document is ENY-867, one of a series of the Entomology and Nematology Department, Florida Cooperative Extension Service, Institute of Food and Agricultural Sciences, University of Florida. Original publication date February 2013. Visit the EDIS website at http://edis.ifas.ufl.edu.

2. Hugh A. Smith, assistant professor, Department of Entomology and Nematology, University of Florida, Gainesville, FL 32611.

The Institute of Food and Agricultural Sciences (IFAS) is an Equal Opportunity Institution authorized to provide research, educational information and other services only to individuals and institutions that function with non-discrimination with respect to race, creed, color, religion, age, disability, sex, sexual orientation, marital status, national origin, political opinions or affiliations. U.S. Department of Agriculture, Cooperative Extension Service, University of Florida, IFAS, Florida A\&M University Cooperative

Extension Program, and Boards of County Commissioners Cooperating. Nick T. Place, Dean 
weeks after transplanting, which makes that period the treatment window: the most important time to treat to protect the plants. Planting resistant varieties, destroying crop residues that serve as a reservoir for TYLCV, and using reflective mulches are key strategies for reducing early infection of the tomato crop. At-plant applications of neonicotinoid insecticides (Group 4A) or cyantraniliprole may also provide important early-season protection from viruliferous whiteflies. Because of the importance associated with insecticides that can help suppress transmission of TYLCV, the early season may be considered a priority "treatment window" for use of cyantraniliprole.

If a diamide is used during the first 35-42 days after transplanting, alternate modes of action should be used instead of diamides for a period of roughly thirty days following the final application of the diamide insecticide. Under this scenario, insecticides that do not include active ingredients with a group 28 mode of action would be used for suppression of whitefly, leafminers, and caterpillars during this second treatment window. For example, group 6 and 17 materials could be used for leafminer, and group 11, 18 , and 22 materials could be used for caterpillar management. "Softer" materials, including materials that have not been assigned an IRAC MOA number, can be included in these insecticide rotations when appropriate. (Spinosyns, group 5 insecticides, are effective against leafminers and caterpillars but should be reserved for thrips management whenever possible. This is because the spinosyns are among the most effective insecticides for managing thrips, and excessive use of spinosyns can lead to the development of resistance among thrips populations.)

Table 1. Insecticides containing diamides available for management of pests of Florida tomato and other crops.

\begin{tabular}{|l|l|l|}
\hline Product & MOA\# & Active ingredient(s) \\
\hline Coragen & 28 & Chlorantraniliprole \\
\hline Durivo (soil) & $28+4 \mathrm{~A}$ & Chlorantraniliprole + thiamethoxam \\
\hline Voliam Xpress & $28+3$ & Chlorantraniliprole + lambda cyhalothrin \\
\hline Voliam Flexi (foliar) & $28+4 \mathrm{~A}$ & Chlorantraniliprole + thiamethoxam \\
\hline Belt & 28 & Flubendiamide \\
\hline Vetica & $28+16$ & Flubendiamide + buprofezin \\
\hline Verimark (soil) & 28 & Cyantraniliprole \\
\hline Exirel (foliar) & 28 & Cyantraniliprole \\
\hline
\end{tabular}


Table 2. Modes of action available for management of whitefly, caterpillars, and leafminers on Florida tomato.

\begin{tabular}{|c|c|c|c|c|c|}
\hline MOA \# & $\begin{array}{l}\text { Grouping or action } \\
\text { site }\end{array}$ & $\begin{array}{l}\text { Active ingredient } \\
\text { examples }\end{array}$ & Silverleaf whitefly & Caterpillars & Leafminers \\
\hline $1 \mathrm{~A}$ & Carbamate & Oxamyl* & $x$ & $x$ & \\
\hline $1 B$ & Organophosphate & $\begin{array}{l}\text { Dimethoate, } \\
\text { methamidophos }\end{array}$ & $x$ & & $x$ \\
\hline 3 & Pyrethroid & $\begin{array}{l}\text { Esfenvalerate, } \\
\text { beta-cyfluthrin*, } \\
\text { bifenthrin, propathrin }\end{array}$ & $x$ & $x$ & \\
\hline $4 \mathrm{~A}$ & Neonicotinoid & $\begin{array}{l}\text { Acetamiprid, } \\
\text { clothianidin*, } \\
\text { imidacloprid, } \\
\text { thiamethoxam }\end{array}$ & $x$ & & \\
\hline 5 & Spinosyns & Spinosad, spinetoram & & $x$ & $x$ \\
\hline 6 & Avermectins & Abamectin & & $x$ & $x$ \\
\hline $7 C$ & $\begin{array}{l}\text { Juvenile hormone } \\
\text { mimics }\end{array}$ & Pyriproxifen & $x$ & & \\
\hline $9 \mathrm{~B}$ & $\begin{array}{l}\text { Selective } \\
\text { homopteran feeding } \\
\text { blocker }\end{array}$ & Pymetrozine* & $x$ & & \\
\hline 11 & $\begin{array}{l}\text { Microbial disruptor } \\
\text { of insect midgut } \\
\text { membrane }\end{array}$ & $\begin{array}{l}\text { Bacillus thuringiensis } \\
\text { subspecies aizawai; } \\
\text { subspecies kurstaki }\end{array}$ & & $x$ & \\
\hline 15 & \multirow{2}{*}{$\begin{array}{l}\text { Inhibitors of chitin } \\
\text { biosynthesis }\end{array}$} & Novaluron & $x$ (nymphs) & $x$ & $x$ \\
\hline 16 & & Buprofezin & x (nymphs) & & \\
\hline 17 & $\begin{array}{l}\text { Dipteran molting } \\
\text { disruptor }\end{array}$ & Cyromazine & & & $x$ \\
\hline 18 & $\begin{array}{l}\text { Ecdysone receptor } \\
\text { agonist }\end{array}$ & $\begin{array}{l}\text { Tebufenozide, } \\
\text { methoxyfenozide }\end{array}$ & & $x$ & \\
\hline $21 \mathrm{~A}$ & METI insecticides & Fenpyroximate & $x$ & & \\
\hline 22 & $\begin{array}{l}\text { Sodium channel } \\
\text { blocker }\end{array}$ & indoxacarb & & $x$ & \\
\hline 23 & $\begin{array}{l}\text { Lipid biosynthesis } \\
\text { inhibitor }\end{array}$ & $\begin{array}{l}\text { Spiromesifen, } \\
\text { spirotetramat }\end{array}$ & $x$ & & \\
\hline 28 & $\begin{array}{l}\text { Ryanodine receptor } \\
\text { modulators }\end{array}$ & $\begin{array}{l}\text { Chlorantraniliprole, } \\
\text { cyantraniliprole, } \\
\text { flubendiamide }\end{array}$ & $\begin{array}{l}\text { Cyantran } \\
\text { iliprole }\end{array}$ & $x$ & $x$ \\
\hline--- & unknown & Azadirachtin & $x$ & $x$ & \\
\hline--- & unknown & Beauvaria bassiana & $x$ & & \\
\hline--- & unknown & Cryolite & $x$ & & \\
\hline--- & unknown & Insecticidal soap & $x$ & & \\
\hline--- & unknown & $\begin{array}{l}\text { Extract of } \\
\text { Chenopodium } \\
\text { ambrosioides }\end{array}$ & $x$ & & $x$ \\
\hline--- & unknown & Stylet oils & $x$ & & $x$ \\
\hline
\end{tabular}

